\title{
KONSEP PENDIDIKAN GOOD NETIZEN MELALUI KURIKULUM TERSEMBUNYI
}

\author{
Muhamad Mustaqim \\ Muhamadmustaqim10@gmail.com
}

\begin{abstract}
Abstrak
This paper examines the education of good netizens through a hidden curriculum. The tendency of internet citizens who prefer to spread insults, hatred and even slander, is a problem for the school. Through an excellent netizen-based education strategy, students can be equipped with the values and character of how to use the internet and become good internet citizens. Procedures that can be done in building good netizens through hidden curricula, namely schools are expected to have an educational ideology oriented to multiculturalism, as well as a school culture that is paradigmatic of love and affection. Besides, the teacher must be able to be a good example, through the learning process, always tucking in the value of tolerance and ethics of internet usage. Finally, schools are expected to be able to build a favorable organizational climate.
\end{abstract}

Kata kunci: good netizen, hidden curricula, character building.

\section{A. Latar Belakang}

Realitas masyarakat, dewasa ini harus dipilah menjadi dua bagian, masyarakat secara nyata dan masyarakat maya. Manusia terhubung melalui 'dunia lain' yang saling menghubungkan, meskipun secara fisik terpisahkan. Inilah era informasi. Benar juga kata Alvin Toffler, Gelombang ketiga dunia adalah gelombang informasi, yang merupakan metamorfosis dan dua gelombang sebelumnya, pertanian dan industri. Dunia maya telah menjadi entitas baru yang melekat pada diri manusia. Melalui internetlah, manusia terhubung, menyapa, belajar dan berekspresi. Komunitas masyarakat pada entitas dunia maya ini sering disebut dengan netizen, masyarakat internet. 
Di dunia maya saat ini, kita sangat sulit membedakan informasi yang benar dan palsu, keduanya sama-sama didukung oleh bukti dokumen yang meyakinkan. Setiap hari kita disuguhi satu berita yang terkadang kita tidak bisa mengetahui sejatinya berita tersebut benar apa tidak. Media sosial setiap menit diisi oleh informasi-informasi yang berkonten kebencian, hasutan bahkan fitnahan. Sampai saat ini, ruang publik kita sudah sangat menghawatirkan, tidak mampu membentuk "ekosistem" kehidupan yang sehat dan bersih.

Media sosial kita, kiranya sudah sangat kotor dan keruh. Ibarat air yang sudah dipenuhi kotoran, dibutuhkan proses filterisasi yang berlapis untuk mendapatkan kualitas air jernih. Proses filterisasi pada ruang publik maya ini tentunya membutuhkan proses dan waktu yang lama. Padahal rumus utama media sosial adalah informasi instan dan cepat. Inilah yang seringkali seseorang mudah mengkonsumsi informasi secara mentah, yang diiringi respon yang "mentah" pula.

Melihat fenomena hoaks yang yang sudah mengakar pada ruang publik kita, kiranya perlu kearifan sikap dalam menghadapinya. Diperlukan sikap kritis terhadap berbagai informasi yang disebarkan di internet dan media sosial. Oleh agama, kita diajarkan untuk tabayyun terhadap segala kabar. Sikap tabayyun, atau secara bahasa berarti mencari pejelasan adalah upaya untuk melakukan klarifikasi, apakah informasi yang masuk itu benar dan bisa dipertanggung jawabkan apa tidak. Lebih lanjut, tabayyun meniscayakan adanya sikap kritis terhadap konten berita, siapa yang menyebarkan, apa motifnya dan sebagainya. Sehingga kita tidak terpapar berita bohong yang bisa mempengaruhi obyektifitas penilaian kita. Kebencian dan kecintaan terhadap sesuatu, seringkali menjadikan kita bersikap tidak adil.

Salah satu tujuan pendidikan adalah bagaimana mengantarkan peserta didik untuk menjadi warga negara yang baik atau good citizen. Pada era informasi seperti saat ini, kiranya tidak cukup hanya menjadikan generasi yang good citizen, namun juga perlu menjadi good netizen, menjadi warga internet yang baik. Berbagai fenomena ucaran kebencian, hujatan, fitnahan yang kerap kali mewarnai ruang publik internet kita kiranya menjadi perhatian bersama, khususnya bagaimana mengurangi kecenderungan tersebut. Dan pendidikan kiranya mempunyai peran besar 
dalam membekali peserta didiknya supaya menjadi warganet yang baik.

Good netizen dalam hal ini adalah sebuah karakter yang bisa dibentuk. Good netizen mengasumsikan profil warga internet yang mampu mengolah, menggunakan dan membagi informasi dengan profesional. Tidak mudah mengkonsumsi informasi yang tidak valid, hoaks apalagi mengandung ujaran kebencian. Selanjutnya informasi yang didapatkan, tidak kemudian diproduksi menjadi sebuah isu, wacana, bahkan ujaran yang mengadung unsur hoaks, fitnah dan kebencian. Hingga nantinya, warganet yang baik, mampu menggunakan internet dan media sosial untuk kebentingan yang baik dan bermanfaat, bukan malah sebaliknya.

Salah satu komponen penting pendidikan yang mampu membekali dan mengantarkan peserta didik dalam mencapai tujuan adalah kurikulum. Kurikulum dapat dipahami sebagai seperangkat/sistem rencana dan pengaturan mengenai isi dan bahan pelajaran serta cara yang digunakan sebagai pedoman untuk menggunakan aktivitas belajar mengajar. Sehingga kurikulum merupakan pedoman dan dasar yang digunakan oleh penyelenggara pendidikan untuk melakukan proses pembelajaran. Karena merupakan sebuah sistem, kurikulum mempunyai komponen-komponen yang saling terkait dan mempengaruhi.

Dalam kaitannya dengan hal ini, kurikulum mempunyai tiga pengertian, pertama, sebagai sejumlah mata pelajaran yang harus ditempuh oleh peserta didik (course of studied), yakni mata pelajaran yang diajarkan kepada peserta didik. Kedua, sebagai pengalaman belajar (learning experiences) yaitu, pengalaman pembelajaran guru yang menjadi acuan dalam proses pembelajaran selanjutnya. Ketiga, sebagai rencana program belajar (learning plan), yakni seperangkat perencanaan yang menjadi dasar dalam pelaksanaan proses pembelajaran (Mudlofir, 2007)

Dalam konteks kurikuum pendidikan, ada yang disebut dengan kurikulum tersembunyi (hidden curriculum). Kurikulum tersembunyi merupakan seperangkat rencana atau konsep yang menjadi acuan dalam pembelajaran dan konsep tersebut tidak tercantum atau tertulis. Beberapa hal tidak ada dalam dokumen atau program yang sifatnya tidak tertulis dan hal ini berpengaruh terhadap hasil tujuan pendidikan disa dikategorikan sebagai kurikulum tersembunyi. 
Peran kurikulum tersembunyi dalam pembentukan karakter siswa khususnya dalam membangun good netizen dalam hal ini menempati titik urgensinya. Melalui kurikulum tersembunyi, akan terbangun tata nilai, kultur, system pembelajaran yang akan mampu membangun karakter dan mentalitas peserta didik. Generasi milenial yang saat ini akrab dengan dunia maya atau internet, harus mampu dibimbim dan di arahkan bagaimana cara berinternet yang baik. Melalui kurikulum tersembunyi, guru atau sekolah dapat memasukkan nilai-nilai karakter untuk membekali siswa menjadi warganet yang baik.

\section{B. Konsep Kurikulum Pendidikan}

1. Pengertian Kurikulum

Istilah kurikulum barangkali bukan merupakan istilah asing bagi kita. Dalam pendidikan, istilah ini sering kali dipakai sebagai bagian dari sistem pendidikan dan pengajaran. Dalam implementasinya, penggunaan istilah kurikulum ini seringkali tumpang tindih dan multitafsir. Dari sini, perumusan istilah kurikulum dalam penelitian ini akan membantu dalam penggunaan dan analisis kurikulum tersebut.

Secara etimologi, kurikulum berasal dari kata latin curriculum. Curir artinya pelari dan curere berarti tempat berlari atau berpacu. Pada awalnya, istilah curriculum ini digunakan dalam dunia olahraga pada zaman Yunani Kuno (Mudhofir, 2009: 3)

Secara terminologi, ada beberapa pendapat tempat istilah kurikulum ini. secara tradisional, kurikulum seringkali diartikan sebagai mata pelajaran yang diajarkan di sekolah (Nasution, 1993: 9).

Secara umum, kurikulum dapat dipahami sebagai seperangkat/ sistem rencana dan pengaturan mengenai isi dan bahan pelajaran serta cara yang digunakan sebagai pedoman untuk menggunakan aktivitas belajar mengajar. Sehingga kurikulum merupakan pedoman dan dasar yang digunakan oleh penyelenggara pendidikan untuk melakukan proses pembelajaran. Karena merupakan sebuah sistem, kurikulum mempunyai komponen-komponen yang saling terkait dan mempengaruhi.

Kurikulum merupakan bentuk operasional yang menjabarkan konsep pendidikan dalam rangka mencapai tujuan pendidikan. Obyek kajian dalam kurikulum tidak terlepas dari tujuan yang dilandasi prinsip dasar 
filsafat yang dipilih, kualifikasi pendidik, kondisi subyek pendidik, materi yang diajarkan, bukuteks, organisasi kurikulum, penjenjangan, metode, bimbingan dan penyuluhan, administrasi, prasarana, biaya lingkungan dan evaluasi (Moh Roqib, 2009:77).

\section{Fungsi Kurikulum}

Mengingat kurikulum merupakan komponen pokok dalam pendidikan, maka ia merupakan "kompas" yang menunjukkan arah, hendak ke mana peserta didik mau dibawa. Pada dasarnya kurikulum itu berfungsi sebagai pedoman atau acuan. Bagi guru, kurikulum itu berfungsi sebagai pedoman dalam melaksanakan proses pembelajaran.

Bagi sekolah atau pengawas, berfungsi sebagai pedoman dalam melaksanakan supervisi atau pengawasan. Bagi orang tua, kurikulurn itu berfungsi sebagai pedoman dalam membimbing anaknya belajar di rumah. Bagi masyarakat, kurikulum itu berfungsi sebagai pedoman untuk memberikan bantuan bagi terselenggaranya proses pendidikan di sekolah. Bagi siswa itu sendiri, kurikulum berfungsi sebagai suatu pedoman belajar

\section{Komponen Kurikulum}

Sebagaimana dijelaskan sebelumnya, bahwa kurikulum merupakan seperangkat sistem yang terdiri dari beberapa komponen. Komponenkomponen ini saling berinteraksi dan berkaitan yang bertugas mewujudkan tujuan kurikulum tersebut. Dari beberapa pendapat tentang komponen kurikulum ini, yang paling sering digunakan adalah empat komponen kurikulum yaitu: tujuan, isi (bahan pelajaran), strategi pelaksanaan (proses belajar mengajar), dan penilaian (evaluasi). Masing-masing komponen saling berkait, untuk mewujudkan sebuah pendidikan atau pembelajaran yang efektif.

\section{Kurikulum Tersembunyi}

Kurikulum tersembunyi merupakan kurikulum yang tidak terstruktur dan tertulis sebagaimana dalam kurikulum formal. Menurut Goodman dan Freidenberg sebagaimana dikutip oleh Ishak Ramli (2003) adalah peraturan yang ditetapkan oleh pihak sekolah bagi mengidenfikasikan struktur kelas serta norma-norma sosial yang perlu diikuti oleh pelajar selama berada dalam lingkungan budaya sekolah. Kurikulum Tersembunyi mengacu pada aturan-aturan atau kebiasaan yang tak tertulis, jika tidak dipahami bisa 
menjadikan sesuatu membingungkan dan membuat kita merasa terisolasi dan keluar dari sana (Blackwell, 2009: 24)

Menurut Philip Jackson, sebagaimana dikutip oleh Colin (1991) mengindikasikan bahwa kebutuhan sosial dari pembelajaran di sekolah seringkali tersembunyi, namun hal itu sangat penting sekali. Jackson menekankan 3 unsur yang harus ada dalam kurikulum tersembunyi, yaitu: dinamika kelas, interaksi antara guru dan siswa dan relasi kuasa. Kurikulum tersembunyi melibatkan pemberlajaran sikap, norma, kepercayaan, nilai dan asumsi yang sering diekspresikan sebagai aturan, ritual dan peraturan (Colin, 1991: 24)

Kurikulum teresmbunyi mempunyai arti bagi pembelajaran, mengenai metode, materi dan strategi, tetapi tidak ada dalam diri mereka sendiri, masuk dalam kesadaran atas pengelolaan lembaga pendidikan atau sekolah (Vic Kelly, 2009: 7). Cakupan kurikulum tersembunyi ini sangatlah luas, termasuk segala bentuk pendidikan, misalnya kegiatan rekreasional, kemasyarakatan, budaya, yang mengajarkan nilai-nilai pelajaran yang sebenarnya tak sengaja. Hak ini karena kurikulum tersembunyi bukan hanya berhubungan dengan sekolah saja namun lebih kepada pengalaman belajar.

Segala bentuk transmisi norma, rasa, nilai, dan kepercayaan yang disampaikan dalam pemndidikan dan interaksi sosial dalam sekolah bisa masuk pada lingkup kurikulum tersembunyi ini. Secara tidak sadar, ideologi menggerakkan sebuah pola pikir masyarakat melalui pendidikan. Hal ini juga bagian dari kurikulum tersembunyi. (Tilaar, 2003). Kurikulum tersembunyi bukan membicarakan masalah isi, namun lebih menekankan pada proses dari apa yang sebenarnya terjadi (Linda Smith, 1991: 258).

\section{Pendidikan Karakter dan Good Netizen}

Konsep karakter, secara istilah mempunyai beberapa nomenklatur, seperti akhlak, budi pekerti, moral, prilaku, relijius dan lainnya. Namun istilah karakter dalam hal ini lebih universal dan komprehensif dalam kaitannya dengan pembentukan jati diri manusia. Dalam hal ini, karakter menyangkut prilaku yang berkaitan dengan norma dan dimensi lain yang terjadi dalam kehidupan manusia. 
Karakter juga bisa dipahami sebagai kumpulan tata nilai yang menuju pada suatu sistem, yang melandasi pemikiran, sikap, dan perilaku yang ditampilkan (Armando, 2008: 238). Dalam definisi yang lain, karakter seringkali identik sama dengan kepribadian. Kepribadian bisa dipahami sebagai ciri, watak atau sifat khas dari diri seseorang yang bersumber dari sesuatu yang didapatkan dari lingkungan, umpamanya lingkungan keluarga pada masa kecil (Doni Koesoema 2007:80).

Jika dikaitkan dengan istilah pendidikan maka pendidikan karakter dapat diartikan sebagai suatu sistem penanaman nilai-nilai karakter kepada peserta didik yang meliputi komponen pengetahuan, kesadaran atau kemauan, dan tindakan untuk melaksanakan seperangkat nilai, baik terhadap Tuhan, diri sendiri, sesama, lingkungan, maupun kebangsaan sehingga menjadi manusia insan kamil.

Dalam pengertian yang lain, pendidikan karakter merupakan segala sesuatu yang dilakukan guru, yang mampu mempengarui karakter peserta didik. Dalam hal ini, keteladanan guru menjadi faktor penting dalam membentuk karakter siswa. Bagaimana prilaku guru, cara guru berbicara atau menyampaikan materi, bagaimana guru bertoleransi, dan bagaimana hal terkait lainnya (Heri Gunawan, 2012 : 23)

Dalam pendidikan karakter di sekolah, semua komponen (stakeholders) harus dilibatkan, termasuk komponen-komponen pendidikan itu sendiri, yaitu isi kurikulum, proses pembelajaran dan penilaian, kualitas hubungan, penanganan atau pengelolaan mata pelajaran, pengelolaan sekolah, pelaksanaan aktivitas atau kegiatan ko-kurikuler, pemberdayaan sarana prasarana, pembiayaan, dan ethos kerja seluruh warga dan lingkungan sekolah.

Melalui pendidikan karakter diharapkan peserta didik mampu secara mandiri meningkatkan dan menggunakan pengetahuannya, mengkaji dan menginternalisasi serta mempersonalisasi nilai-nilai karakter dan akhlak mulia sehingga terwujud dalam perilaku sehari-hari. (Mochtar Buchori 2007),

Pada tingkatan institusi, pendidikan karakter mengarah pada pembentukan budaya sekolah, yaitu nilai-nilai yang melandasi perilaku, tradisi, kebiasaan keseharian, dan simbol-simbol yang dipraktikkan oleh semua warga sekolah, dan masyarakat sekitar sekolah. Budaya sekolah 
merupakan ciri khas, karakter atau watak, dan citra sekolah tersebut di mata masyarakat luas.

Kaitanya dengan good netizen, maka pendidikan karakter nantinya juga akan mampu membangun warga internet yang baik. Dalam hal ini rumusan tentang good netizen akan menggunakan konsep good citizen, warga negara yang baik. Konsep warga negara yang baik ini pada dasarnya menjadi muara tujuan pendidikan dari hampir semua mata pelajaran ilmu sosial (social sciences). Warga negara yang baik adalah karakter ideal dari warga sebuah negara, yang memiliki berbagai perbedaan baik budaya, bahasa, usia, suku, agama dan kultural yang lainnya. Menjada warga negara yang baik berarti mampu hidup bersama dengan warga negara lainnya dengan damai, toleran dan saling bekerja sama atau gotong royong.

Ada beberapa karakter warga negara ideal (good citizen) yang nantinya bisa menjadi indikator dalam pembangunan karakter melalui pendidikan, khususnya kurikulum tersembunyi. Sebagaimana dirumuskan oleh Kementerian Pendidikan dan kebudayaan, melalui Direktorat Jenderal Manajemen Pendidikan Dasar dan Menengah, ada tiga karakter dasar dalam pembentukan warga negara yang baik ini. Pertama, civic intellegence, yaitu kecerdasan dan daya nalar warga negara baik dalam dimensi spiritual, rasional, emosional, maupun sosial. Kecerdasan kewargaan akan menjadikan warga negara yang cerdas dalam memahai realitas, karena didukung oleh tiga aspek kecerdasan dasar, yakni spiritual, rasional, emosional dan sosial.

Kedua, civic responsibility, kesadaran akan hak dan kewajiban sebagai warga negara yang bertanggung jawab. Ada kesadaran dalam memahami hal dan kewajiban bagi dirinya dan warga negara lain, dan semuanya itu harus ditunaikan secara proporsional dan seimbang. Ketiga, civic particiption, kemampuan berpartisipasi warga negara atas dasar tanggung jawabnya, baik secara individual, sosial, maupun sebagai pemimpin masa depan.

\section{E. Strategi Membangun Good Netizen Melalui Kurikulum Tersembunyi}

Sebagaimana dijelaskan sebelumnya bahwa kurikulum tersembunyi merupakan kurikulum yang tidak dicantumkan dalam kurikulum resmi 
sekolah. Dalam hal ini, bisa diimplementasikan melalui budaya sekolah, pola interaksi warga sekolah, pembelajaran guru serta atribut yang ada dalam lingkungan sekolah. Menurut Wina Sanjaya (2007: 26), ada dua aspek yang dapat mempengaruhi perilaku dalam kurikulum tersembunyi ini..

\section{Aspek relatif tetap}

Hal yang dimaksudkan dengan aspek relatif tetap adalah ideologi, keyakinan, nilai budaya masyarakat yang mempengaruhi sekolah dalam arti bahwa budaya masyarakat yang menetapkan pengetahuan mana yang perlu diwariskan pada generasi mendatang suatu bangsa.

Pada aspek ini ada beberapa strategi yang bisa dilakukan dalam membangun good citizen. Pertama, Sekolah harus memiliki ideologi pendidikan yang berorientasi pada multikulturalisme. Visi sekolah harus menyerap nilai-nilai multikulturalisme, toleransi, inklusif dan mengakui keragaman. Langit internet sat ini dipenuhui oleh mayoritas generasi milenial. Sebagian besar generasi milenial tersebut adalah mereka yang masih mengenyam bangku pendidikan. Jika pada sektor hulu ini, yakni sekolah kita membangun multikulturalisme dalam berbangsa maka sikap arogansi dan suka menebar kebencian para netizen ini lambat laun bisa diminimalisasi.

Kedua, Budaya yang dibangun di sekolah adalah budaya cinta dan kasih sayang. Saat ini virus kebencian dan berita bohong (hoaks) begitu menyesaki dunia maya kita. Apapaun yang dilakukan oleh orang yang berseberangan dengan (kepentingan) kita maka seringkali kita anggap sebagai kesalahan. Inilah paradigma kebencian dalam melihat realitas. Tak jarang, sering kali netizen debat kusir karena persoalan yang tak penting. Apapun komentar dari "kubu sebelah" seringkali ditanggapi dengan sumpah serapah, cercaan dan fitnah. Budaya kasih sayang harus mulai menjadi budaya sekolah. Jangan biarkan peserta didik mendapatkan ruang sekecil apapun untuk membenci, khususnya pada sesama teman dan warga sekolah lainnya.

Kajian yang dilakukan oleh Sabani (2018) tentang debat kusir generasi milenial media sosial menyimpulkan bahwa debat kusir virtual sebagai suatu bentuk perdebatan yang berlangsung sengit, tanpa 
mempedulikan substansi dan acuan data yang valid. Karena debat, yang sejatinya merupakan hal positif dalam rangka mencari kebenaran, tetapi justru menjadi aktivitas yang berlandaskan, berlangsung serta berujung pada ketidakjelasan dan pada akhirnya hanya akan menjadi perbuatan siasia.

Pemahaman akan paradigma kebencian harus selalu dimasukkan dalam budaya pendidikan di sekolah. Dan dalam hal yang paling konkrit, siswa harus dibatasi dalam menggunakan ponsel cerdas, khususnya aplikasi media sosial. Kecenderungan penggunaan media sosial yang tidak dilandasai dengan semangat pertemanan dan "cinta" akan mudah menjadikan seseorang hilang kontrol, mudah menyebarkan berita bohong dan ujuran kebencian. Membangun budaya yang baik ini nantinya akan menjadi tradisi yang terwariskan dari generasi ke generasi.

2. Aspek yang dapat berubah

Aspek yang dapat dirubah meliputi variabel organisasi sistem sosial dan kebudayaan. Variabel organisasi meliputi bagaimana guru mengelola kelas, bagaimana pelajaran diberikan, bagaimana interaksi pembelajaran. Sistem sosial meliputi bagaimana pola hubungan sosial guru dengan guru; guru dengan kepala sekolah; guru dengan peserta didik; guru dengan staf sekolah dan lain sebagainya.

Beberapa strategi yang bisa dilakukan dalam implementasi good netizen pada ranah yang kedua ini diantaranya:

Pertama, Guru harus mampu menjadi contoh yang baik. Hal ini memang terkesan normatif dan klise, namun hal ini sangat signifikan dalam membentuk karakter siswa. Guru harus mampu menjadi suri tauladan kebaikan, baik dalam interaksi pembelajaran, maupun di luar hal tersebut, termasuk dalam hal ini di dunia maya, sebagai warga internet. Di media sosial, tidak sedikit guru yang justru menjadi bagian dari oknum penyebar ujaran kebencian. Jika hal ini diketahui oleh siswa, maka siswa akan melakukan lebih dari yang dilakukan guru. Jika kita hendak mengajarkan toleransi kepada siswa, maka guru harus membangun sikap toleransi terlebih dahulu.

Kedua, melalui proses pembelajaran, guru harus selalu menyelipkan nilai toleransi dan etika penggunaan internet, khususnya dalam bermedia 
sosial. Segala bentuk cacian dan ujuran kebencian, baik yang dilakukan di dunia nyata maupun di dunia maya adalah sesuatu yang tidak diperbolehkan. Undang-Undang tentang Informasi dan transaksi elektronik (ITE) memberi kriteria bagaimana cara menjadi warganet yang baik, serta batasan-batasan yang menghindarkan dari tindak pidana di dunia maya ini.

Siswa harus semenjak dini dipahamkan akan tanggung jawab kewargaan, yang meliputi pemenuhan antara hak dan kewajiban sebagai warga negara, termasuk warga internet. Hak dan kewajiban ini yang akan mengatur pola interaksi dan komunikasi di dunia maya, bahwa teman kita mempunyai hak yang harus kita berikan. Ketika kita semena-mena dalam berinternet, maka secara langsung atau tidak langsung, ada hak teman kita yang terampas, terlukai dan terkurangi. Sehingga pemahaman ini akan semakin menjadikan kita lebih bijak dalam berinternet.

Ketiga, sekolah harus mampu membangun iklim organisasi yang kondusisf. Iklim organisasi ini mengatur pola interaksa antar semua warga sekolah, termasuk di media sosial. Saat ini, hampir semua komunitas memiliki WA group, yang terkadang menjadi bibit-bibit aawal adanya ujuran kebencian. Sekolah setidaknya mampu mengingatkan akan peran pentingnya membangun komunikasi yang baik, yang humanis, tidak mudah membagikan informasi yang bisa memecah belah warga sekolah dan amsyarakat.

Semua langkah ini adalah bagian dari kurkulum tersembunyi, yang mungkin saja tidak termakstub dalam (materi) kurikum yang diterapkan di sekolah. Namun dengan adanya kurikulum tersembunyi ini, sejara tidak sadar, setikit demi sedikit mampu dibangun warga internet (netizen) yang baik, yang mampu memahami perbedaan dan menggunakan paradigma "cinta" dalam berinternet. Strategi ini mungkin tidak mampu dibaca secara riil, namun dapat terukur melalui perilaku warga sekolah ketika menjadi netizen di dunia maya. Evaluasi dan penilaian terhadap karakter yang diharapkan dari kurikulum tersembunyi ini bisa dilakukan secara periodik.

\section{F. Simpulan}

Kurikulum tersembunyi merupakan seperangkat sistem yang mempengaruhi tujuan pendidikan, namun tidak termaktub di dalam kurikulum formal. Kurikulum ini bisa berupa ideologi, budaya, sistem 
sosial, pola interaksi dan komunikasi, model pembelajaran yang diarahkan pada tujuan tertentu. Era informasi meniscayakan manusia untuk "eksis" tidak hanya di kehidupan nyata, namun juga dunia maya, yaitu menjaga warga internet (warganet/netizen). Menjadi netizen yang baik saat ini menjadi tantangan bagi masyarakat, khususnya generasi milenial.

Kurikulum tersembunyi dalam hal ini bisa menjadi bagian dari upaya untuk menjadikan warga internet yang baik (good netizen). Beberapa strategi yang bisa dilakukan diantaranya: pertama, sekolah harus memiliki ideologi pendidikan yang berorientasi pada multikulturalisme. Kedua, budaya yang dibangun di sekolah adalah budaya cinta dan kasih sayang. Ketiga, guru harus mampu menjadi contoh yang baik. Keempat, melalui proses pembelajaran, guru harus selalu menyelipkan nilai toleransi dan etika penggunaan internet, khususnya dalam bermedia sosial. Kelima, sekolah harus mampu membangun iklim organisasi yang kondusif.

\section{Referensi}

Armando, Ade dkk. (2008). Refleksi Karakter Bangsa. Jakarta: Forum Kajian Antropologi Indonesia.

Blackwell, Jen, et.al. (2009) Hidden Curriculum One Day Calendar for Kids. USA: APC.

Gunawan, Heri. (2012). Pendidikan Karakter Konsep Dan Implementasi. Bandung: Alfabeta.

Kelly, Vic. (2009) The Curriculum: Theory and Practice. California: Thousand Oaks.

Koesoema, Doni. (2007). Pendidikan Karakter. Jakarta: Grasindo.

Marsh, Colin J . (1992) Key Concept for Understanding Curriculum. USA: The Falmer Press.

Mudhofir, Ali \& Ahmad, Masyudi. (2008). Pengembangan Kurikulum Dan Bahan Ajar Madrasah Ibtidaiyyah. Surabaya: IAIN Sunan Ampel.

Nasution. (1993). Pengembangan Kurikulum. Bandung: Citra Aditya Bakti. 
Nasution. (2010) Manajemen Mutu Terpadu. Jakarta: Galia Indonesia.

Ramli, Iskak. (2003). Inilah Kurikulum Sekolah. Kuala Lumpur: PTS.

Roqib, Moh. (2009). Ilmu Pendidikan Islam. Yogyakarta: LKIS.

Sabani, Noveliyati. (2018). Generasi Milenial dan absurditas Debat Kusir Virtual. Jurnal Informasi: Kajian Ilmu Komunikasi, Vol. 48 No 1.

Sanjaya, Wina. (2007) Kurikulum dan Pembelajaran: Teori dan Praktik Pengembangan Kkurukulum Tingkat Satuan Pendidikan (KTSP). Bandung : Alfa Beta.

Smith, Linda. (1991). Ide-ide Filsafat dan Agama, Dulu dan Sekarang. Yogyakarta: Kanisus.

Tilaar, H.A.R. (2003). Kekuasaan dan Pendidikan (Suatu Tinjauan dari Perspektif Studi Kultural). Magelang: Indonesia Tera. 